\title{
THE STAINING OF BACTERIAL CAPSULES AND SLIME WITH FERRIC COMPOUNDS
}

\author{
BY \\ M. C. BERENBAUM \\ From the Department of Pathology, Chase Farm Hospital, Enfield, Middlesex
}

(RECEIVED FOR PUBLICATION APRIL 18, 1955)

In 1946 Hale described a method for demonstrating acid mucopolysaccharides in sections based on the affinity of these compounds for colloidal iron oxide in acid solution. The combined iron was demonstrated by conversion to prussian blue.

It has been found that bacterial capsules and slime are very well stained by Hale's method. This is possibly due to their content of acid mucopolysaccharides, but this is not certain, since doubts have been cast on the specificity of this reaction (Pearse, 1953).

The method of Rinehart and Abul-Haj (1951) is also applicable, but the iron solution is troublesome to prepare and the results are no better than with Hale's method.

The following technique is based on Hale's method, but saccharated iron oxide is used, resulting in considerably deeper staining.

\section{Method}

(1) Thin films of saline suspensions are dried and fixed by heat.

(2) Equal volumes of "ferrivenin" (Benger) and $2 M$ acetic acid are mixed, centrifuged, and the slide is flooded with the clear supernate. It is then left for one to 10 minutes.

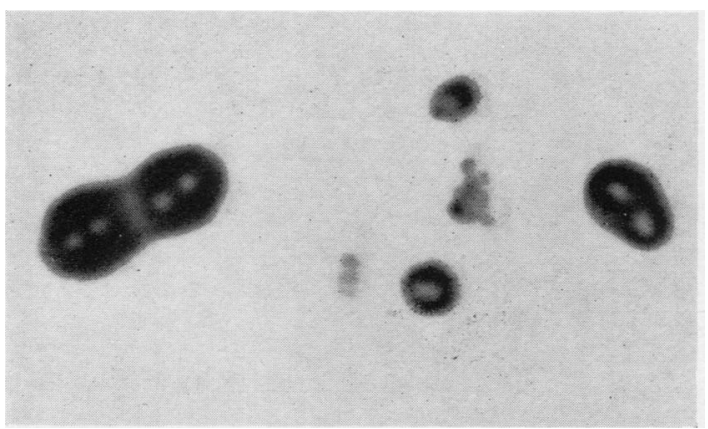

FIG. 1.-Str. pneumoniae Type III. Saccharated iron oxide, $\times$ approximately 2,500 .
(3) The slide is washed well in distilled water.

(4) It is flooded with a mixture of equal volumes of $0.14 \mathrm{M}$ hydrochloric acid and $0.02 \mathrm{M}$ potassium ferrocyanide and left for 10 minutes.

(5) It is washed in distilled water.

(6) If desired it is counterstained in $1 \%$ neutral red.

\section{Results}

Capsules and slime stain deep blue (Figs. 1 and 2). Thick capsules may be almost black, while thin slime layers are more often greenish blue.

The great majority of bacteria show a peripheral blue-stained layer, more marked when the organisms are in a mucoid phase.

Some organisms, e.g., Staphylococcus citreus, may be stained throughout, with deeper blue rims.

Many bacilli, e.g., Salmonella, B. proteus, $P$ s. pyocyanea, $\mathrm{Cl}$. welchii, show a bipolar concentration of blue-stained material.

Bacilli containing spores, e.g., B. cereus, $\mathrm{Cl}$. sporogenes, show deep, uniform staining of the bacillary body, the spore being unstained.

\section{Notes}

Once acidified, the colloidal iron solutions are unstable and slowly throw down a precipitate. The solutions must therefore be centrifuged or

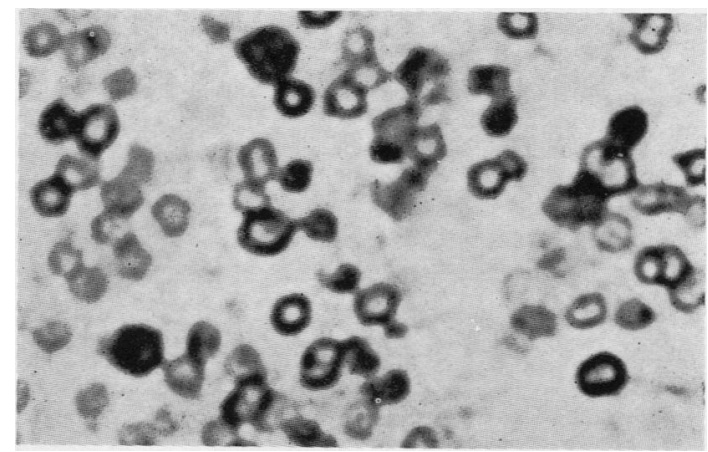

FIG. 2.-Str. pyogenes Group C. Saccharated iron oxide, $\times$ approximately 2,500 . 
filtered on the day of use if they are kept for more than one day. Acidified "ferrivenin" has given unimpaired results after keeping for three months, but Hale's and Rinehart and Abul-Haj's stains give progressively weaker staining on storage and it is best to add the acid just bafore use.

A dextran-saccharated iron oxide complex and another preparation of saccharated iron oxide available commercially gave very weak staining.

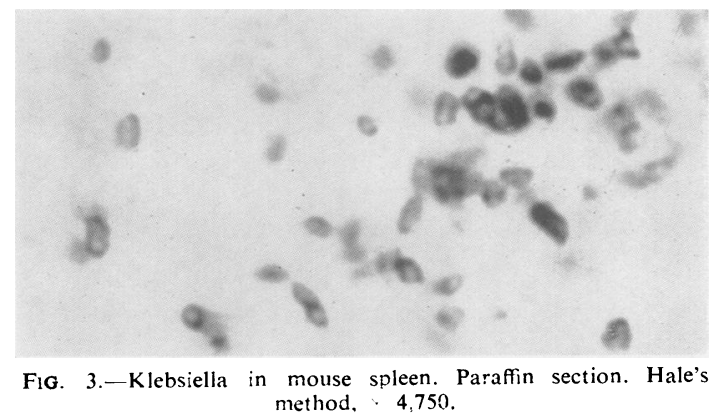

Potassium ferrocyanide solution should be stored in the dark to delay the yellowing which it $\underline{\text { ㅇ }}$ slowly undergoes and which is accompanied by a $\underset{\vec{D}}{\stackrel{0}{0}}$ weakening of the final stain.

If bacterial capsules are to be stained in paraffin sections Hale's method should be used (Fig. 3). $\frac{\sigma}{\bar{c}}$ Saccharated iron oxide stains other tissue $\vec{\nabla}$ components too deeply to be used for this $\frac{2}{0}$ purpose.

Slime is stained more intensely if ammonium $\overrightarrow{0}$ sulphide is substituted for acidified ferrocyanide. The results are not permanent, however.

I wish to thank Dr. H. Loewenthal, Senior Patho- $\bar{O}$ logist at Chase Farm Hospital, for his interest and 0 help in this work. Mr. H. Knight took the photographs.

\section{REFERENCES}

Hale, C. W. (1946). Nature, Lond., 157, 802

Pearse, A. G. E. (1953). Histochemistry, Theoretical and Applied. Churchill, London.

Rinehart, J. F., and Abul-Haj, S. K. (1951). Arch. Path., Chicago, 52, 189. 